DOI: $10.19195 / 0080-3626.61 .7$

BOŻENA KUMOR-GOMUŁKA

\title{
OD SPORU DO KSIĘGOZBIORU, CZYLI O POSEKULARYZACYJNEJ GENEZIE I ROZWOJU IDEI GROMADZENIA LITERATURY FACHOWEJ W DAWNYM ARCHIWUM PAŃSTWOWYM WE WROCŁAWIU (STAATSARCHIV BRESLAU) DO 1945 ROKU
}

Trudności w utworzeniu biblioteki archiwalnej w pierwszych latach istnienia Archiwum na skutek sporów między archiwistą J.G.G. Büschingiem a dyrektorem Centralnej Biblioteki Śląskiej J.G. Schneiderem. Pierwsze nabytki biblioteczne. Działalność Wilhelma Wattenbacha. Nabytki, organizacja i pomieszczenia biblioteki archiwalnej do 1945 roku.

SŁOWA KLUCZOWE: Archiwum Państwowe we Wrocławiu, Staatsarchiv Breslau, księgozbiór fachowy

Profesjonalne i w pełni świadome podejście do właściwych archiwistom obowiązków już od zarania dziejów wrocławskiego Archiwum Państwowego powiązane było z koniecznością wspierania pracy codziennej wiedzą zawartą w odpowiedniej literaturze. Rozumiana zarówno w kategoriach publikacji o charakterze stricte podręcznym ${ }^{1}$, jak i wydawnictw - w szerszym znaczeniu tego słowa - historyczno-archiwalnych, stanowiła jeden z rodzajów gromadzonych sukcesywnie pomocy fachowych, nabierając $\mathrm{z}$ czasem statusu zbioru uzupełniającego materiały archiwalne. Racjonalnie wyposażona biblioteka naukowa bogata w księgozbiór historyczny, dostępny tak archiwistom, jak wszystkim użytkownikom badającym dawne teksty, oraz zasobna w wydawnictwa niezbędne w rozwiązywaniu kwestii czysto warsztatowych, stanowi w dobie dzisiejszej integralną część każdej rozwijającej się instytucji archiwalnej. U podstaw obecnych realiów znalazł się wszak wysoki poziom świadomości potrzeb profesji właściwy już pierwszym organizatorom archiwistyki wrocławskiej doby posekularyzacyjnej,

${ }^{1}$ Pierwsze rozprawy mające na celu sformułowanie zasad pracy archiwalnej powstawały jeszcze przed wiekiem XIX. Podwaliny pod powstanie archiwistyki jako nowej dyscypliny naukowej dał jednak dopiero XIX-wieczny rozwój archiwów. W II połowie XIX wieku pojawiają się też pierwsze ujęcia syntetyczne w zakresie metodologii, takie jak: Handbuch der Registratur und Archivwissenschaft G. Holtzingera (Leipzig 1883) czy Archivlehre F. von Löhera (Paderborn 1890). 
w szczególności zaś inicjatywy podejmowane przez — powołanego w 1810 roku z ramienia Głównej Komisji Sekularyzacyjnej do zabezpieczania dóbr kulturalnych na Śląsku — królewsko-pruskiego komisarza do spraw bibliotek, archiwów i zbiorów sztuki Johanna Gustava Gottlieba Büschinga ${ }^{2}$.

Za pierwszą siedzibę Archiwum - organizowanego w następstwie ogłoszenia w dniu 30 października 1810 roku edyktu sekularyzacyjnego i połączonego wkrótce z utworzoną w 1811 roku Śląską Biblioteką Centralną (Schlesische Zentralbibliothek) oraz podlegającego jej kierownictwu - obrano, wespół z całokształtem przejętych zbiorów poklasztornych, budynek dawnego klasztoru kanoników regularnych św. Augustyna (augustianów) na Piasku (obecnie ul. św. Jadwigi $3 / 4)^{3}$. Funkcję archiwisty — po wykluczeniu tegoż z prac Biblioteki Centralnej - powierzono J.G.G. Büschingowi ${ }^{4}$. Wysuwana przez Büschinga ambitna potrzeba zorganizowania niewielkiego księgozbioru fachowego, przydatnego w rzetelnym wykonywaniu obowiązków archiwisty, znacząco akcentowana była już w pierwszych latach aktywności, gdy początkowy, posekularyzacyjny entuzjazm współpracy ustąpić musiał miejsca konsekwencjom sukcesywnego krystalizowania się odrębnych, archiwalnych i bibliotecznych, rewirów działalności. Właściwy pierwszym posekularyzacyjnym realiom fantom Śląskiej Biblioteki Centralnej wszystkich „opiekunów” zbiorów zjednoczonych w fundacji na Piasku uznawał za pracowników tej samej instytucji, niepozbawionych, jak mogłoby się wydawać, wynikających z tego faktu przywilejów. Należało do nich, nieogra-

2 Osobę J.G.G. Büschinga wiąże się z projektem utworzenia we Wrocławiu Śląskiej Biblioteki Centralnej (Schlesische Zentralbibliothek). Podstawowym założeniem planu Büschinga było scalenie wszystkich bibliotek wrocławskich, wybranych księgozbiorów prowincjonalnych, w tym najważniejszych klasztornych i innych. W rozbudowanym przez siebie projekcie uwzględniał Büsching także dzieła sztuki, archiwalia, jak też zorganizowanie Instytutu Antykwarycznego oraz bibliotek w głównych miastach księstw - Brzegu, Świdnicy, Legnicy i Jeleniej Górze.

3 Śląska Biblioteka Centralna, funkcjonująca de facto w latach 1811-1815, powstała przez połączenie księgozbiorów wrocławskiego Uniwersytetu Jezuickiego (Leopoldiny), Uniwersytetu we Frankfurcie na Odrą (Viadriny) i kilkudziesięciu bibliotek zlikwidowanych klasztorów śląskich. W 1815 roku przyjęła nazwę Biblioteki Królewskiej i Uniwersyteckiej (Königliche- und Universitätsbibliothek), w latach 1919-1945 funkcjonowała jako Biblioteka Państwowa i Uniwersytecka (Staatsund Universitätsbibliothek). W budynku dawnego klasztoru augustianów na Piasku (po 1945 roku Biblioteka Uniwersytecka, Zbiory Specjalne) zgromadzono wszystkie przejęte w efekcie sekularyzacji zbiory archiwalne, biblioteczne i muzealne. Archiwalia przechowywano tam aż do roku 1847.

${ }^{4}$ Funkcję archiwisty (nie zaś pierwszego dyrektora, jak niekiedy mylnie się uważa) w Archiwum Prowincji Śląskiej pełnił J.G.G. Büsching w latach 1812-1825. O okolicznościach zaprzestania przez niego działalności na polu organizowania zasobu Śląskiej Biblioteki Centralnej zob. M. Walter, Pruska sekularyzacja klasztorów w dziejach Biblioteki Uniwersyteckiej we Wrocławiu, [w:] Druga Konferencja Naukowa Komisji Bibliografii i Bibliotekoznawstwa Wrocławskiego Towarzystwa Naukowego, Wrocław 3-5. XI. 1954. Referaty i dyskusja, Wrocław 1957 („Śląskie Prace Bibliograficzne i Bibliotekoznawcze" 4), także J. Ożóg, Zarys historii Biblioteki Uniwersyteckiej we Wrocławiu, Wrocław 1995 („Acta Universitatis Wratislaviensis No 1637. Bibliothecalia Wratislaviensia" 1). 
niczone wymogami formalnymi, prawo korzystania archiwisty z przydatnego w pracy codziennej księgozbioru gromadzonego w zasobach Śląskiej Biblioteki Centralnej. Narzucało to model swoistej „samoobsługi”, w którym pracownik Archiwum czuł się w pełni upoważniony do wolnego wstępu na teren Biblioteki i samodzielnego, swobodnego wyboru potrzebnej literatury.

Przybyły z Frankfurtu nad Odrą w listopadzie 1811 roku, z ostateczną misją objęcia wiosną 1812 roku funkcji naczelnego bibliotekarza Śląskiej Biblioteki Centralnej, otoczony nimbem naukowego autorytetu Johann Gottlob Schneider ${ }^{5}$ nie okazał się zwolennikiem zbyt daleko posuniętej — zdaniem pryncypialnego profesjonalisty — „wspólnoty” użytkowania zgromadzonych na Piasku zbiorów. Relacjonowany w literaturze, zaistniały wkrótce przykry incydent pomiędzy archiwistą Büschingiem - faktycznym projektodawcą i pierwszym organizatorem Biblioteki Centralnej — a formalnie stojącym na jej czele od 25 marca 1812 roku Schneiderem przyniósł rychły kres wcześniejszym udogodnieniom. Okoliczność niespodziewanego natknięcia się w pomieszczeniach bibliotecznych na ,archiwalnego intruza" $\mathrm{i}$ wyrażona $\mathrm{w}$ związku z tym przez naczelnego bibliotekarza, $\mathrm{z}$,niepohamowaną gwałtownością”, głęboka dezaprobata dla sytuacji zastanej okazały się być wystarczającym impulsem ku spontanicznemu pojawieniu się w planach ambitnego archiwisty zamysłu utworzenia niewielkiego, ale niezależnego księgozbioru archiwalnego. Epizod „konfliktu o książkę”, postrzegany jako jeden z przejawów personalnych i kompetencyjnych sporów pomiędzy nieznoszącym sprzeciwu Schneiderem a młodym, pełnym zapału i zaangażowania Büschingiem, stał się tym samym zalążkiem inicjatywy zrodzonej, paradoksalnie, $\mathrm{z}$ arogancji i demonstrowanej wobec archiwisty wrogości osobistej ${ }^{7}$. Dodatkowy asumpt w sprawie dała opinia Akademickiej Komisji Organizacyjnej ${ }^{8}$, która,

5 Johann Gottlob Schneider, z wykształcenia filolog klasyczny, w latach 1805-1811 pełnił obowiązki bibliotekarza Biblioteki Uniwersytetu Frankfurckiego.

6 B. Krusch, Geschichte des Staatsarchivs zu Breslau, Leipzig 1908, s. 260 („Mitteilungen der K. Preussischen Archivverwaltung” 11). O zaistniałym pomiędzy Büschingiem a Schneiderem incydencie informuje także F. Milkau w publikacji Die Königliche und Universitäts-Bibliothek, [w:] Festschrift zur Feier des hundertjährigen Bestehens der Universität Breslau. Cz. 2, Geschichte der Fächer, Institute und Ämter der Universität Breslau 1811-1911, pod red. G. Kaufmanna, Breslau 1911, s. 569. Jak relacjonuje Milkau, Schneider w swej „niepohamowanej gwałtowności” (,in ungezügelter Heftigkeit”) zastanego w pomieszczeniu bibliotecznym Büschinga, którego miejsce pracy jako archiwisty znajdowało się piętro wyżej, wyrzucił za drzwi.

7 Źródeł licznych sporów, zwłaszcza kompetencyjnych, upatrywać można w szczególności w uznawanym dziś powszechnie fakcie głębokich zaniedbań Schneidera jako kontynuatora, w miejsce Büschinga, akcji przewłaszczeniowej dóbr kulturalnych sekularyzowanych klasztorów. Przyczyną było uprzedzenie do Büschinga i ostateczne wyeliminowanie go z prac nad zabezpieczaniem zbiorów.

8 Do końca 1811 roku Śląska Biblioteka Centralna podlegała lokalnie we Wrocławiu Głównej Komisji Sekularyzacyjnej, od 1812 roku zaś Akademickiej Komisji Organizacyjnej (F. Milkau, op. cit., s. 552). 
w interesie utrzymania organizacyjnego ładu, poparła, optujące za zachowaniem całkowitej odrębności obu rewirów, kategoryczne stanowisko Schneidera.

Büsching, traktowany odtąd na prawach formalnego użytkownika Biblioteki Centralnej, zobowiązany został tym samym do oficjalnego składania rewersów na każdą żądaną publikację. W sytuacji, gdy konieczność sprostania obowiązkom archiwisty wymagała codziennego użytkowania wybranych tytułów, regularnie ponawiane przez Archiwum zamówienia skutkowały stałą nieobecnością książek w magazynach bibliotecznych. Wysuwaną przez Büschinga, na nieprzyjaznym dla siebie gruncie, koncepcję utworzenia niewielkiego archiwalnego księgozbioru podręcznego drogą przekazania 20-30 dubletów z zasobu Biblioteki Centralnej odrzucono jednak - stosownie do wyrażonej w sprawie negatywnej opinii Schneidera ${ }^{9}$. Charakterystyczne już od pierwszych dekad XIX wieku poszukiwanie najwłaściwszych metod pracy archiwalnej wymagało wsparcia każdą dostępną, a pomocną literaturą. Świadomy popartych rzeczową argumentacją własnych racji, nieustępujący w zabiegach Büsching, po podjęciu ostatecznych kroków odwoławczych, zyskał z czasem przychylność pruskiego Ministra Spraw Wewnętrznych Caspara Friedricha Schuckmanna ${ }^{10}$. W sytuacji permanentnej zaciętości naczelnego bibliotekarza, stosownie zaś do zaleceń ministerialnych, wyrażone przez archiwistę życzenie bezpośredniego dostępu do pozycji bibliotecznych o szczególnej wartości - z punktu widzenia potrzeb administracji archiwalnej - Schneider winien był ostatecznie uwzględnić w regulaminie udostępniania zbiorów Biblioteki Centralnej ${ }^{11}$.

Brak odpowiednich źródeł uniemożliwia dokładne przebadanie kwestii negatywnego ustosunkowania się Schneidera do nakazu Schuckmanna. Wiadomym jest, iż „konflikt o książkę” wciąż nie tracił na aktualności jeszcze w roku 1815, gdy urząd pierwszego dyrektora Królewskiego Akademickiego Archiwum Prowincjonalnego (Königliches Akademisches Provinzial-Archiv), w następstwie formalnego oddzielenia zbiorów archiwalnych od Biblioteki ${ }^{12}$, objął Johann

9 Ibidem, s. 572.

10 Jeszcze przed objęciem stanowiska Ministra Spraw Wewnętrznych w roku 1814, od końca 1810 roku pełnił Schuckmann funkcję tajnego radcy Ministerstwa jako szef Departamentów Handlu i Przemysłu oraz Departamentu Kultury i Oświaty Publicznej.

11 Tymczasowy regulamin korzystania ze zbiorów Biblioteki Centralnej, opracowany przez Schneidera 20 kwietnia 1812 roku, zatwierdzony został przez Akademicką Komisję Organizacyjną 14 maja 1812 roku. W dniu 19 maja 1815 roku ukazało się zarządzenie ministerialne nadające Bibliotece nowy regulamin, w którym nosiła już ona nazwę Biblioteki Królewskiej i Uniwersyteckiej. W regulaminie, który wszedł w życie 13 listopada 1815 roku, nie było jednak mowy o specjalnych zasadach udostępniania pozycji bibliotecznych personelowi Archiwum (Ibidem, s. 559-560, 580-581).

12 Formalne oddzielenie zbiorów archiwalnych od Biblioteki nastąpiło dokładnie 27 października 1815 roku. Przekształcono wówczas Archiwum w samodzielną komórkę w ramach Uniwersytetu - Królewskie Akademickie Archiwum Prowincjonalne (Königliches Akademisches Provinzial-Archiv). Archiwum zgromadziło ponad 33 tysiące dokumentów, zebranych przez 
Friedrich Ludwig Wachler ${ }^{13}$. Poparte dyrektorskim autorytetem kolejne próby zorganizowania podręcznego księgozbioru archiwalnego ponownie spotkały się ze zdecydowanym sprzeciwem butnego Schneidera. Towarzysząca odmownym decyzjom wrogość naczelnego bibliotekarza wobec zrodzonej już inicjatywy i jej twórcy skłoniła życzliwego planom archiwalnym opiekuna Archiwum z ramienia Rejencji Wrocławskiej, radcę rejencyjnego Friedricha Wilhelma Neumanna, do opracowania nowego projektu współpracy. Nakazem Neumanna zestawiono wkrótce wykaz pożądanych przez Archiwum tytułów 14 dzieł z zasobu Biblioteki Centralnej, z gwarancją wypożyczenia na czas nieokreślony. Jako rozwiązanie alternatywne, wobec jednoczesnego braku dubletów tytułów wybranych i niedostatku archiwalnych środków, zobowiązano Schneidera do jak najrychlejszego nabycia publikacji ze specjalnego funduszu przeznaczonego na pomnażanie zbiorów Biblioteki Centralnej i natychmiastowego odstąpienia ich na potrzeby Archiwum ${ }^{14}$.

Pełna wersja projektu Neumanna, popierającego całkowicie koncepcję utworzenia osobnego księgozbioru jako niezbędnego merytorycznego wsparcia w obecnych i przyszłych pracach personelu archiwalnego ${ }^{15}$, przewidywała dostarczenie wykazu dubletów bibliotecznych do rąk dyrektora Wachlera z jednoczesnym, skierowanym w stronę Akademickiej Komisji Organizacyjnej, nakazem odstąpienia Archiwum „bez jakichkolwiek wątpliwości” dubletów dzieł z zakresu historii Śląska. Warunkiem sine qua non było przy tym, przysługujące obdarowanemu, prawo pierwszeństwa w nabywaniu wspomnianych dzieł, do czego predestynował Archiwum fakt przekształcenia go z dniem 27 października 1815 roku w samodzielny Instytut Uniwersytetu. Do zrealizowania postanowień Neumanna jednak wówczas nie doszło, a to ze względu na zgłoszenie przez Schneidera potencjalnych trudności z tym związanych. Przy równoczesnym braku jednoznacznych decyzji w sprawie ze strony Ministra Spraw Wewnętrznych projekt utworzenia chociażby zalążka biblioteki archiwalnej ponownie odłożono.

Swoiste i zaskakujące, pozbawione perspektywicznego spojrzenia na potrzeby Archiwum okazało się stanowisko kolejnego dyrektora instytucji, powołanego na ten urząd w 1822 roku Gustava Adolfa Haralda Stenzla. Przeznaczając znaczną część własnych dochodów na skompletowanie osobistej biblioteki podręcznej, wspaniale zaopatrzonej w ilościowo i merytorycznie bogaty zbiór dzieł przydatnych w wykonywaniu czynności zawodowych, potrzebę zorganizowania

Büschinga ze zsekularyzowanych klasztorów (V. Loewe, Das Deutsche Archivwesen. Seine Geschichte und Organisation, Breslau 1921, s. 41).

13 Stosunkowo mało znany jest fakt pełnienia przez J.F.L. Wachlera funkcji pierwszego oficjalnego dyrektora Archiwum wrocławskiego. Z wykształcenia historyk i historyk literatury, kojarzony jest powszechnie z Biblioteką Uniwersytecką, jako jej dyrektor w latach 1824-1838.

14 B. Krusch, op. cit., s. 261.

15 Współpracownikiem Büschinga był już wówczas Johann Karl Friedrich Jarick, który podjął się opracowania znacznej liczby dokumentów poklasztornych. 
księgozbioru „służbowego” odsuwał na plan dalszy ${ }^{16}$. O ile planom archiwalnym nie zagrażały już wpływy zmarłego w 1822 roku Schneidera, o tyle nie do końca uświadamiana ignorancja dyrektora Stenzla zagrozić mogła realizacji tak długo prowadzonych zabiegów. Jakkolwiek starania Stenzla pozbawione były intensywności i uporu jego poprzedników, efektem wystosowanego przez tegoż w roku 1831 wniosku o zakup niezbędnych książkowych pomocy archiwalnych było nabycie tytułów takich, jak: Schlesische Curiositäten Johanna Sinapiusa ${ }^{17}$ w 1833 roku oraz, w dwa lata później, Repertorium autorstwa Karla Friedricha Vatera $^{18}$. Wkrótce też, drogą przekazów czynionych ze strony Ministerstwa Spraw Wewnętrznych, wrocławska instytucja - funkcjonująca od 1822 roku pod nową nazwą Królewskiego Śląskiego Archiwum Prowincjonalnego (Königliches Schlesisches Provinzial-Archiv) - stała się właścicielem kolejnej partii dzieł, wśród których znalazła się m.in. publikacja z zakresu heraldyki autorstwa Christiana Samuela Theodora Bernda ${ }^{19}$.

Przeprowadzona w 1821 roku przez kanclerza Karla A. von Hardenberga reforma pruskiej administracji zagwarantowała Archiwum wrocławskiemu, wraz z przywilejem pełnej samodzielności, nowe warunki funkcjonowania. Działające wcześniej w charakterze centralnego archiwum klasztornego, pozyskało odtąd prawo przejmowania także akt państwowych z terenu całej Prowincji Śląskiej. Kontynuowanie zwielokrotnionych teraz prac i obowiązków związanych z porządkowaniem zasobu archiwalnego, który do roku 1830 wzrósł aż dwudziestokrotnie, bezwarunkowo wymagało wspomożenia wiedzą ,ukrytą” w naukowej literaturze. Funkcjonowanie w nowych realiach wyzwalało wiele pytań badawczych, na które należało poszukiwać odpowiedzi. Pojawienie się w Archiwum

16 Wydaje się to tym bardziej zaskakujące, zważywszy na fakt, że to właśnie Stenzel zabierając głos w dyskusji nad aktualnym w tym czasie problemem zjednoczenia księgozbiorów wrocławskich - wyrażał swą dezaprobatę dla braku jednego, zorganizowanego księgozbioru śląskoznawczego, stwierdzając wręcz: „Czy można w to uwierzyć, że nigdzie dotychczas nie ma publicznego, poniekąd kompletnego zbioru źródeł do historii Śląska? Nawet w takim mieście jak Wrocław”. Doceniając wartość księgozbiorów „zorganizowanych”, nawoływał tym samym do założenia jednej, dużej „Biblioteki historii Śląska”, która miałaby gromadzić wszystkie tematyczne dzieła drukowane oraz najistotniejsze prace ogólne z zakresu historii Polski, Czech, Węgier i Niemiec (K.G.W. Stenzel, Gustaw Adolf Harald Stenzels Leben, Gotha 1897, s. 269).

17 Mowa o: J. Sinapius, Schlesischer Curiositäten erste Vorstellung, darinnen die ansehnlichen Geschlechter des Schlesischen Adels [...] (Leipzig 1720), oraz idem, Des Schlesischen Adels anderer Theil, oder Fortsetzung Schlesischer Curiositäten [...] (Leipzig und Breslau 1728).

18 Pełny tytuł publikacji brzmiał: Repertorium der preussischen schlesischen Verfassung (Breslau 1798).

19 Dokładny tytuł dzieła nie jest dziś znany. Z dużym prawdopodobieństwem chodzi jednak o 4-tomowe Allgemeine Schriftenkunde der gesamten Wappenwissenschaft (Leipzig 1830-1841) lub, uznawane za główne dzieło Bernda, 2-tomowe Die Hauptstücke der Wappenwissenschaft (Bonn 1841-1849). Wspomniane przekazy książkowe tworzyły w przyszłości zasadniczą treść korespondencji lokalnych władz zwierzchnich z Archiwum, w szczególności po śmierci F.W. Neumanna w roku 1834 (B. Krusch, op. cit., s. 261-262). 
pierwszych urzędowych przekazów książkowych, jak też publikacji nabytych z funduszy archiwalnych, wciąż było jednak zaledwie zwiastunem ukształtowania się w niedalekiej już przyszłości — w charakterze wyodrębnionej komórki biblioteki archiwalnej. Gdy w 1847 roku przeniesiono zasób Śląskiego Archiwum Prowincjonalnego do nowej siedziby w Domu Stanów Śląskich przy Graupenstrasse 11a (obecnie ul. Krupnicza) ${ }^{20}$, zbiorom książkowym przeznaczono odtąd obszerny, dwuokienny ogrzewany pokój biurowy od strony zachodniej gmachu, gdzie ulokowano je wraz z repertoriami archiwalnymi i rękopisami ${ }^{21}$.

Znamienne jest, iż do połowy XIX wieku zarówno kilka przybytków książek drukowanych, jak i map spisano w ogólnym inwentarzu archiwalnym. Twórcą osobnego katalogu akcesji dla zbiorów bibliotecznych okazał się dopiero, piastujący od 1855 roku funkcję dyrektora Archiwum, przybyły z Berlina Wilhelm Wattenbach. Cechujące nowego dyrektora obowiązkowość i skrupulatność znajdowały swe odzwierciedlenie w wysokiej dbałości o każdą kategorię gromadzonych w instytucji zbiorów. Szczególną zaś staranność wykazywał Wattenbach w kwestiach odpowiednio prowadzonej statystyki archiwalnej. Jednym z tego przejawów było nabycie specjalnej księgi wypożyczeń (Verleihebuch), celem rejestrowania w niej wszystkich wypożyczanych archiwaliów oraz druków ${ }^{22}$.

Poważnym sprzymierzeńcem Wattenbacha w dziele organizowania wewnętrznego księgozbioru archiwalnego okazał się ówczesny dyrektor pruskich Archiwów Państwowych Karl Wilhelm von Lancizolle ${ }^{23}$. Brak typowej biblioteki podręcznej, której namiastkę do chwili śmierci Stenzla w roku 1854 stanowił w dużej mierze - jego doskonale zaopatrzony zbiór prywatny, uznał Lancizolle za na tyle dotkliwy, by konieczność natychmiastowego, formalnego zorganizowania księgozbioru fachowego przedstawić jako jedno z najistotniejszych zadań archiwalnych. Okazywane ze strony Lancizollego żywe zainteresowanie sprawą i nadanie jej odpowiedniej wagi, wobec obowiązującego jeszcze faktu posiadania przez Archiwum wrocławskie statusu instytucji prowincjonalnej, świadczyć może zarówno o szerokim otwarciu tegoż na problemy archiwalne, jak i o poważnie już ugruntowanej w połowie XIX wieku randze Archiwum. Stosownie do sugestii

20 Od 1899 roku dawny budynek Stanów Śląskich stanowił siedzibę Śląskiego Muzeum Rzemiosła Artystycznego i Starożytności (Schlesisches Museum für Kunstgewerbe und Altertümer). Gmach wyburzono w 1945 roku.

${ }^{21}$ Ibidem, s. 282. Pozostałe dziewięć pomieszczeń archiwalnych znajdowało się od strony północnej budynku, wszystkie zaś zlokalizowane były na parterze. Łączna powierzchnia wszystkich lokali zajmowanych przez Archiwum wynosiła 7700 stóp kwadratowych (ok. $550 \mathrm{~m}^{2}$ ). Domniemywać można, że wspomniane zbiory książkowe kształtował, w przewadze, prywatny księgozbiór Stenzla.

22 Ibidem, s. 293. Księga wypożyczeń (Verleihebuch) aż do 1900 roku służyła jako dziennik odwiedzin archiwalnych (Besuchjournal) do rejestrowania indywidualnych korzystających.

${ }^{23}$ K.W. von Lancizolle, prawnik i historyk prawa, pełnił obowiązki dyrektora pruskich Archiwów Państwowych w latach 1852-1866. 
Lancizollego biblioteka winna była ukierunkować swój profil na gromadzenie najbardziej pożądanych w pracy archiwisty dzieł ogólnych z zakresu literatury pomocniczej, w szczególności zaś wszelkich najbardziej znaczących silesiaców. Środki na cel powyższy zamyślał Lancizolle zmobilizować drogą zagospodarowania pensji zmarłego dyrektora Stenzla, przy jednoczesnym oddaniu do natychmiastowej dyspozycji kwoty 40 talarów z puli wydatków nadzwyczajnych ${ }^{24}$.

Sformułowane przez Lancizollego pierwsze wytyczne gromadzenia zbiorów przyszłej - z prawdziwego zdarzenia - biblioteki Archiwum stanowiły istotny krok w kierunku przekształcenia dotychczasowego „luźnego” zasobu książkowego w indywidualną, archiwalną komórkę. Rozmachu nadawały sprawie poważne negocjacje w kwestii nabycia dla Archiwum księgozbioru zmarłego dyrektora Stenzla. Skromnym życzeniem Wattenbacha pozostawała chęć przejęcia, w charakterze trwałej własności, najistotniejszej części zbioru w postaci licznie zgromadzonych w nim silesiaców. Bezskuteczne początkowo rokowania w sprawie nabycia biblioteki Stenzla nabrały rozmachu z chwilą formalnego jej zakupu przez jedną z wrocławskich księgarń, a następnie przedstawienia z jej strony skierowanej do Archiwum propozycji zakupu, już jako oferty księgarskiej. Konieczność pośrednictwa firmy księgarskiej w nabyciu zbioru spowodowana była faktem trudnego położenia materialnego pozostawionej bez środków do życia rodziny zmarłego, dla której jedyny majątek stanowił dochód ze sprzedaży posiadającego znaczną wartość księgozbioru ${ }^{25}$. Zakup silesiaców, jak też innych niezbędnych w pracy archiwalnej publikacji, za kwotę 336 talarów stanowić miał wystarczającą bazę dla utworzenia dostatecznie zaopatrzonej, w pierwszej fazie jej organizowania, biblioteki archiwalnej ${ }^{26}$. Niewątpliwą zachętą ku przeprowadzeniu transakcji była przewidywana w perspektywie możliwość sukcesywnego pomnażania tak znakomicie zapoczątkowanego zbioru. Szczególną wartość prezentowanej oferty podkreślały licznie reprezentowane w niej publikacje wzbogacone rękopiśmiennymi dopiskami Stenzla. W pełni przekonany o słuszności argumentacji dyrektor Lancizolle przeznaczył wkrótce odpowiednie środki na zakup księgozbioru ${ }^{27}$, tworząc tym samym solidne podstawy dla dalszego rozwoju biblioteki Archiwum. Hojność w kwestii jej rozbudowy wykazywał także wielokrotnie w następnych latach.

Okazywana odtąd, z coraz większym zaangażowaniem, dbałość o rozbudowę „fachowego warsztatu” była jednym z przejawów głębokiego zainteresowania dyrekcji Archiwum wrocławskiego w — ze wszech miar pełny — rozwój in-

24 Ibidem, s. 296.

25 W chwili śmierci w 1854 roku G.A.H. Stenzel pozostawił żonę i dziewięcioro dzieci. $\mathrm{Z}$ uwagi na gorliwą służbę i zasługi Stenzla na niwie archiwalnej wdowa otrzymała wkrótce zapo$\operatorname{mog}$ z $\mathrm{z}$ funduszu dyspozycyjnego.

26 Ibidem.

27 Ani liczba, ani tytuły książek nabytych z biblioteki podręcznej Stenzla nie są znane. Ich wartość obliczona na kwotę 336 talarów sugeruje jednak, iż mógł to być w istocie księgozbiór duży, szacowany orientacyjnie na kilkaset pozycji. 
stytucji. Już w 1858 roku zakupiono za kwotę 36 talarów 130 tomów periodyku „Schlesische Provinzialblätter”28, a wobec dotkliwie odczuwanego braku literatury pomocnej w rozumieniu licznych dokumentów w języku czeskim Wattenbach skorzystał wkrótce z okazji nabycia Stownika czesko-niemieckiego autorstwa Josefa Jungmanna ${ }^{29}$. Stworzyło to możliwość sukcesywnego opracowywania wspomnianych dokumentów, zaniedbywanych wcześniej z uwagi na trudności językowe. Zasłużonym darczyńcą licznych publikacji książkowych okazał się sam Wattenbach, jak również najbliższy jego współpracownik, bez reszty oddany sprawom archiwalnym Johann Ernst Beinling ${ }^{30}$. Wyobrażenie o liczebności ówczesnego zbioru ułatwia znajomość faktu, iż cała długa ściana pokoju biurowego wypełniona była, aż po sufit, regałami książkowymi ${ }^{31}$. Poważne zaangażowanie Wattenbacha w sprawy organizacji biblioteki zaowocowało opracowaniem przez tegoż w latach 50. XIX wieku alfabetycznego katalogu kartkowego jej zbiorów, kontynuowanego z powodzeniem również w wieku XX. Ukończony w 1859 roku systematycznie uporządkowany katalog topograficzny (Standortkatalog) zastąpiono w międzyczasie katalogiem nowszym, przyjmując za podstawę układu kart podział zastosowany w katalogu pierwotnym ${ }^{32}$.

Fakt zaginięcia w efekcie działań II wojny światowej materiałów aktowych, zawierających tajniki prowadzonej pomiędzy Archiwum a lokalnymi władzami zwierzchnimi korespondencji w sprawie przekazów książkowych, jak również wszelkiej dokumentacji bibliotecznej, uniemożliwia dziś ustalenie chociażby szacunkowych danych na temat tempa przyrostu gromadzonej w Archiwum literatury fachowej ${ }^{33}$. Analogiczną trudność stanowi przytoczenie tytułów publikacji najistotniejszych czy też najbardziej dla zasobu charakterystycznych. Będące zasadniczą podstawą opracowania niniejszego artykułu fragmentaryczne dane faktograficzne, dostępne w nader ograniczonej liczbie publikacji tematycznych, pozwalają jedynie na nakreślenie ogólnego wizerunku i nie do końca wyrazistej dynamiki procesu ilościowo-jakościowego rozwoju archiwalnej książnicy.

${ }^{28}$ Czasopismo założone w 1785 roku przez K. Streita i F. Zimmermanna, w latach 18261829 redagowane przez J.G.G. Büschinga. Ostatni tom ukazał się w roku 1849. Regionalny profil czasopisma nadawał mu rangę podstawowego źródła do badania dziejów Śląska.

${ }_{29}$ Tytuł oryg. Slovník česko-německý (Praha 1834-1839). Słownik zawierał 120 tysięcy haseł.

30 J.E. Beinling - długoletni pracownik Królewskiego Śląskiego Archiwum Prowincjonalnego, pełnił obowiązki dyrektora instytucji w latach $1854-1855$, tuż po śmierci G.A.H. Stenzla i przed objęciem urzędu przez W. Wattenbacha.

31 C. Grünhagen, Wattenbach in Breslau 1855-1862, „Zeitschrift des Vereins für Geschichte und Alterthum Schlesiens" 32, Breslau 1898, s. 346.

32 B. Krusch, op. cit., s. 297.

33 Należy w tym miejscu zaznaczyć, że w obecnym zasobie Archiwum Państwowego nie zachował się praktycznie żaden ślad po materiałach aktowych w postaci sprawozdań, korespondencji itp., których analiza mogłaby z pewnością naświetlić obraz ogólnie pojętej działalności dawnego Staatsarchiv Breslau. 
Za okres mało sprzyjający finansowemu dostatkowi rozwijającej się instytucji archiwalnej uznaje się lata 60. XIX wieku. Dyrektor Archiwów Państwowych Lancizolle, mając na względzie ekonomiczne rozporządzanie archiwalnym funduszem kancelaryjnym, stał się zatwardziałym orędownikiem najdalej posuniętych oszczędności. Opiewający na kwotę zaledwie 100 talarów fundusz, którego administrowania doglądała Główna Kasa Rejencji Wrocławskiej, po pokryciu wynagrodzenia portiera i wydatków na ogrzewanie kurczył się do połowy i tę kwotę przeznaczano na potrzeby pozostałe. Wobec powyższych realiów dalsze kształtowanie archiwalnego księgozbioru podręcznego poprzez zakup publikacji najnowszych mogło odbywać się jedynie drogą korzystania z subwencji nadzwyczajnych $^{34}$. Sytuację ratowały w szczególności donacje prywatne oraz przekazy z urzędów państwowych. Wielki przyrost księgozbioru, co przyczyniło się tym samym do głębszego sprofilowania zasobu, zanotowała biblioteka w latach 70 . XIX wieku, kiedy wzbogaciła się w liczne starsze dzieła o tematyce prawniczej, zbędne dla instytucji sądowych Prowincji Śląskiej ${ }^{35}$.

Rozwiązaniu stale aktualnych problemów lokalowych dotychczasowego Królewskiego Śląskiego Archiwum Prowincjonalnego sprzyjać miało, potencjalnie, włączenie instytucji w 1867 roku do państwowej sieci archiwalnej i nadanie jej statusu archiwum państwowego (Staatsarchiv). Urząd służyć miał też odtąd zarówno nauce, jak i administracji. Zakończone w październiku 1876 roku przeniesienie zasobów Archiwum Państwowego do nowo wybudowanego - dzięki uzyskaniu od władz centralnych stosownych kredytów — jednego z pierwszych w Prusach własnego budynku archiwalnego, zlokalizowanego przy Neue Taschenstrasse 17 (obecnie ul. Hugona Kołłątaja) u zbiegu z Gartenstrasse (obecnie ul. Józefa Piłsudskiego ${ }^{36}$, w najbliższej okolicy Dworca Głównego, nie sprzyjało, paradoksalnie, intensywnemu rozrostowi zbiorów bibliotecznych. Oszacowana na zaledwie 150 (!) tomów rezerwa magazynowa dla nabytków biblioteki podręcznej nie gwarantowała większych szans na możliwy w perspektywie dynamiczny przyrost jej zasobu. W celu optymalnego rozlokowania księgozbioru już zgromadzonego wypełniano regałami książkowymi nawet ściany wąskiego i ciasnego gabinetu - pełniącego od 1862 roku funkcję dyrektora Archiwum - Colmara Grünhagena. Zasadniczą część zbiorów bibliotecznych umieszczono zaś w niewystarczająco obszernym pokoju służącym użytkownikom Archiwum, gdzie, z uwagi na ograniczoność powierzchni nieracjonalnie i nieekonomicznie - jak okazało się wkrótce — zaprojektowanego gmachu, zorganizowano jednocześnie

34 Ibidem, s. 310.

35 Oddaniu do dyspozycji Archiwum Państwowego publikacji książkowych towarzyszyło przekazanie ogromnej liczby starszych archiwaliów z Wyższego Sądu Krajowego (Ibidem, s. 346).

36 W miejscu wyburzonego po 1906 roku gmachu archiwalnego w dwa lata później zakończono budowę hotelu „Kronprinz” (obecnie Hotel „Piast”). 
stanowiska pracy dla trzech urzędników naukowych, pracownika kancelarii oraz woźnego archiwalnego ${ }^{37}$.

Wnioskowanie o możliwościach zarówno rozbudowy księgozbioru, jak i funkcjonowania całej instytucji archiwalnej w warunkach nieroztropnie ,zagwarantowanych" przez Grünhagena ${ }^{38}$ nie mogłoby prowadzić do sformułowań optymistycznych. Przyjęte z czasem, dla sprostania niewygodzie ciasnoty, rozwiązanie przechowywania jednostek archiwalnych w podwójnych rzędach ${ }^{39}$ zastosowano, z dużym prawdopodobieństwem, także dla zbiorów bibliotecznych.

Systematyczny wzrost ogólnego zasobu Archiwum i skali jego wykorzystania, przy równolegle postępującej rozbudowie administracji wewnętrznej, stanęły u podstaw podjętej w początkach XX wieku decyzji o wzniesieniu nowego budynku archiwalnego, w pełni dostosowanego do wszelkich potrzeb instytucji. Odpowiedzią na potrzeby wynikające z ogólnej rozbudowy pruskiej administracji państwowej było zaś m.in. tworzenie coraz lepiej zaopatrzonych księgozbiorów fachowych. Nowoczesny gmach, oddany do użytku w roku 1906, usytuowany przy Tiergartenstrasse 13 (obecnie ul. Marii Curie-Skłodowskiej) u zbiegu z ówczesną Dickhutstrasse (obecnie ul. Nauczycielska), zaprojektowany z uwzględnieniem najnowszych technik budownictwa archiwalnego, w sposób przemyślany i planowy zapewniać miał wygodę funkcjonowania każdej komórce archiwalnej w najdalej idącej perspektywie ${ }^{40}$ (il. 1).

Zlokalizowaną od strony zachodniej część wyższej kondygnacji budynku administracyjnego ${ }^{41}$ przeznaczono na zorganizowanie osobnej, specjalistycznej Biblioteki i obszernej Pracowni Naukowej, w której ulokowano fragment księgozbioru o charakterze podręcznym (il. 2). Na regałach ustawionych wzdłuż najdłuższej ściany pomieszczenia Pracowni, naprzeciwko okien, znalazły miejsce encyklopedie, słowniki, kompendia z zakresu geografii i genealogii, zasadnicze publikacje $\mathrm{z}$ dziedziny nauk prawnych, nauk pomocniczych historii, dzieła z zakresu historii regionalnej i powszechnej, nadto najbardziej znaczące śląskie wydawnictwa źródłowe, w dalszej kolejności regionalne czasopisma historyczne oraz księgi adresowe (il. 3). Drugim co do wielkości pokojem budynku admini-

37 Ibidem, s. 334.

38 Wyboru posesji pod budowę gmachu archiwalnego, bez dokonania jej oceny pod kątem możliwości potencjalnej rozbudowy obiektu, dokonał osobiście dyrektor C. Grünhagen.

39 K. Wutke, Die Entwicklung des Breslauer Staatsarchivs, Breslau 1922, s. 12 (Sonderabdruck aus der „Sonntagsbeilage” der „Schlesischen Volkszeitung” vom 14. und 21. Mai).

40 Do 1945 roku zgromadzono w budynku Archiwum najważniejsze akta historyczne Prowincji Śląskiej, w tym ok. 50 tysięcy dokumentów, 250 tysięcy woluminów akt i 30 tysięcy ksiąg archiwalnych.

41 Od przełomu XIX i XX wieku w europejskim budownictwie archiwalnym coraz częściej stosowano tzw. system rozdzielny, według którego założeń część magazynowa, przeznaczona dla archiwaliów, oddzielona była od części administracyjnej przeznaczonej na pokoje archiwistów, salę dla użytkowników, kancelarię itp. Łączność pomiędzy oboma modułami budynku zapewniały, krótsze lub dłuższe, łączniki. 


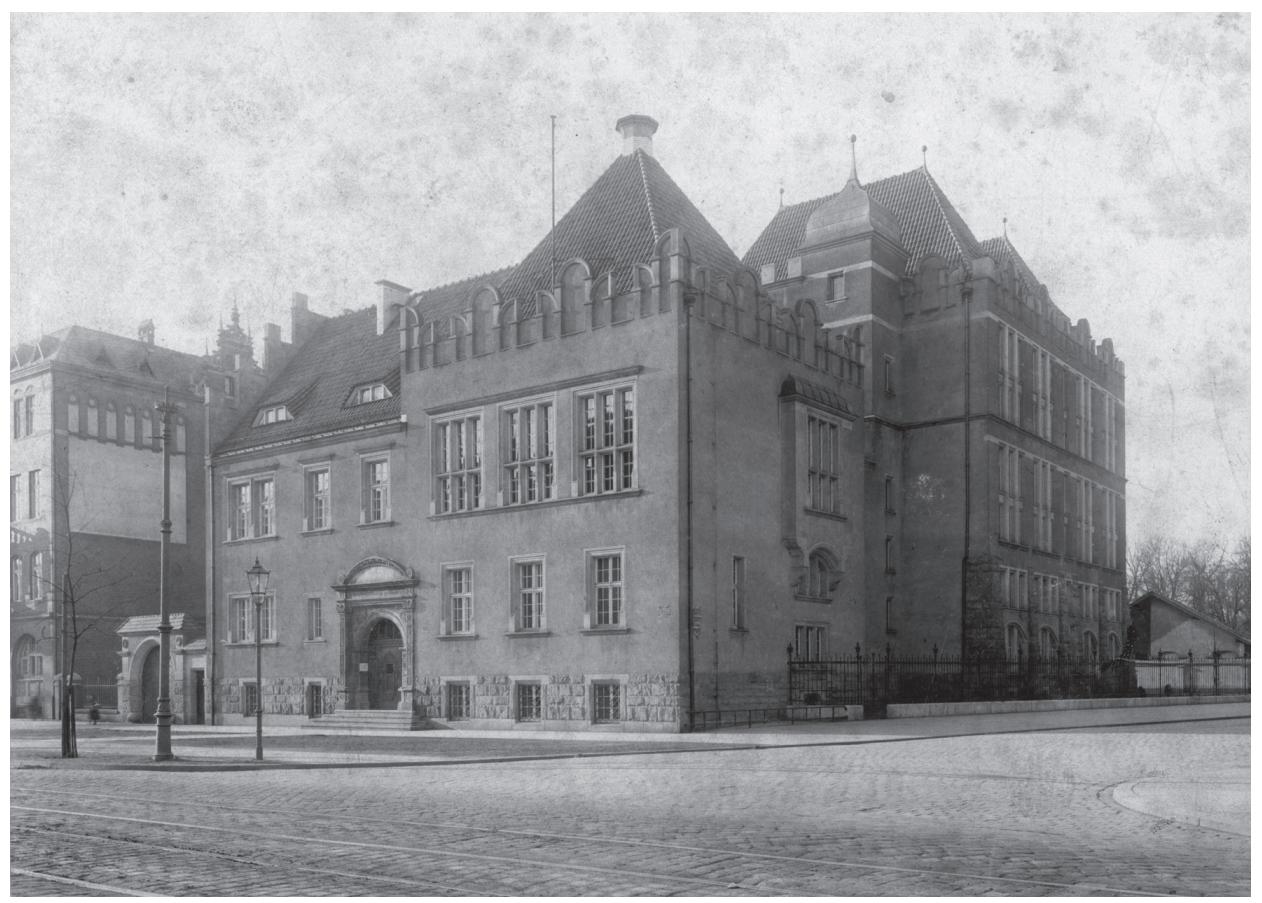

I1. 1. Nieistniejący dziś gmach Archiwum Państwowego przy Tiergartenstrasse 13 (obecnie ul. M. Curie-Skłodowskiej), z widoczną na pierwszym planie częścią administracyjną budynku, ok. 1910 r. (APWr., Zbiór Ikonograficzny, sygn. 1027)

stracyjnego był wydzielony, zasadniczy lokal biblioteczny o powierzchni ponad $30 \mathrm{~m}^{2}$ i, analogicznie jak w przypadku Pracowni Naukowej, wysokości 5,30 m, z wejściem bezpośrednio sąsiadującym z prowadzącymi do niej drzwiami. Dostateczne oświetlenie pomieszczenia Biblioteki gwarantowało światło dzienne, docierające poprzez szerokie i wysokie okno umieszczone w wykuszu ściany zachodniej budynku. Typowe wyposażenie pokoju uzupełniały, umiejscowione tutaj: jedna $\mathrm{z}$ dwóch szaf na mapy ${ }^{42}$, szafa na odlewy pieczętne oraz gablotka do eksponowania księgarskich nowości wydawniczych. Księgozbiór przechowywano na ustawionych wzdłuż ścian nowoczesnych regałach Lipmana, nad którymi rozciągała się na wysokości 2,80 m elegancka galeria, mieszcząca sześć dodatkowych rzędów książek. Wprowadzone rozwiązanie umożliwiało wykorzystanie na potrzeby Biblioteki całej powierzchni ścian nader wysokiego pomieszczenia ${ }^{43}$.

42 Druga identyczna szafa znajdowała się w Pracowni Naukowej.

43 O. Meinardus, R. Martiny, Das neue Dienstgebäude des Staatsarchivs zu Breslau und die Gliederung seiner Bestände, Leipzig 1909, s. 8-10 („Mitteilungen der K. Preussischen Archivverwaltung" 12). 


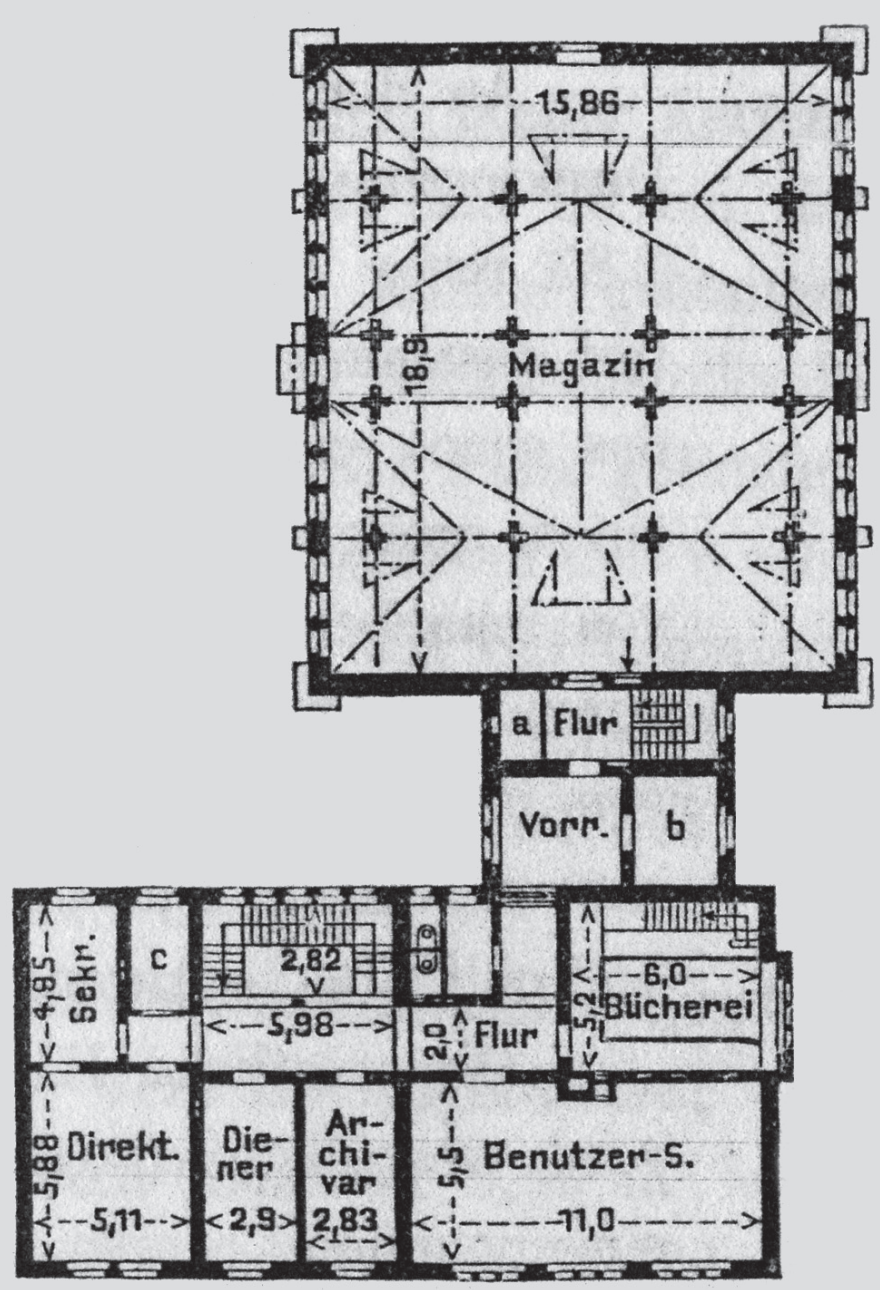

Il. 2. Rzut I piętra budynku archiwalnego przy Tiergartenstrasse 13, z zaznaczonymi w części administracyjnej pomieszczeniami Pracowni Naukowej i Biblioteki (repr. za: O. Meinardus, R. Martiny, Das neue Dienstgebäude des Staatsarchivs zu Breslau und die Gliederung seiner Bestände $<$ Mitteilungen der K. Preussischen Archivverwaltung, H. 12>, Leipzig 1909, s. 7)

Szacowany w pierwszej dekadzie XX wieku na kilka do kilkunastu tysięcy tomów zasób biblioteczny ${ }^{44}$, przy uwzględnieniu stałego przyrostu o liczne nabytki najnowsze, wymagał jednakże powierzchni bardziej obszernych aniżeli te,

44 Dokładna wielkość zasobu Biblioteki Archiwum Państwowego w tym czasie nie jest niestety znana. Podana w przybliżeniu liczba książek, z uwzględnieniem ówczesnych warunków lokalowych, stanowi jedynie subiektywną opinię autorki. 


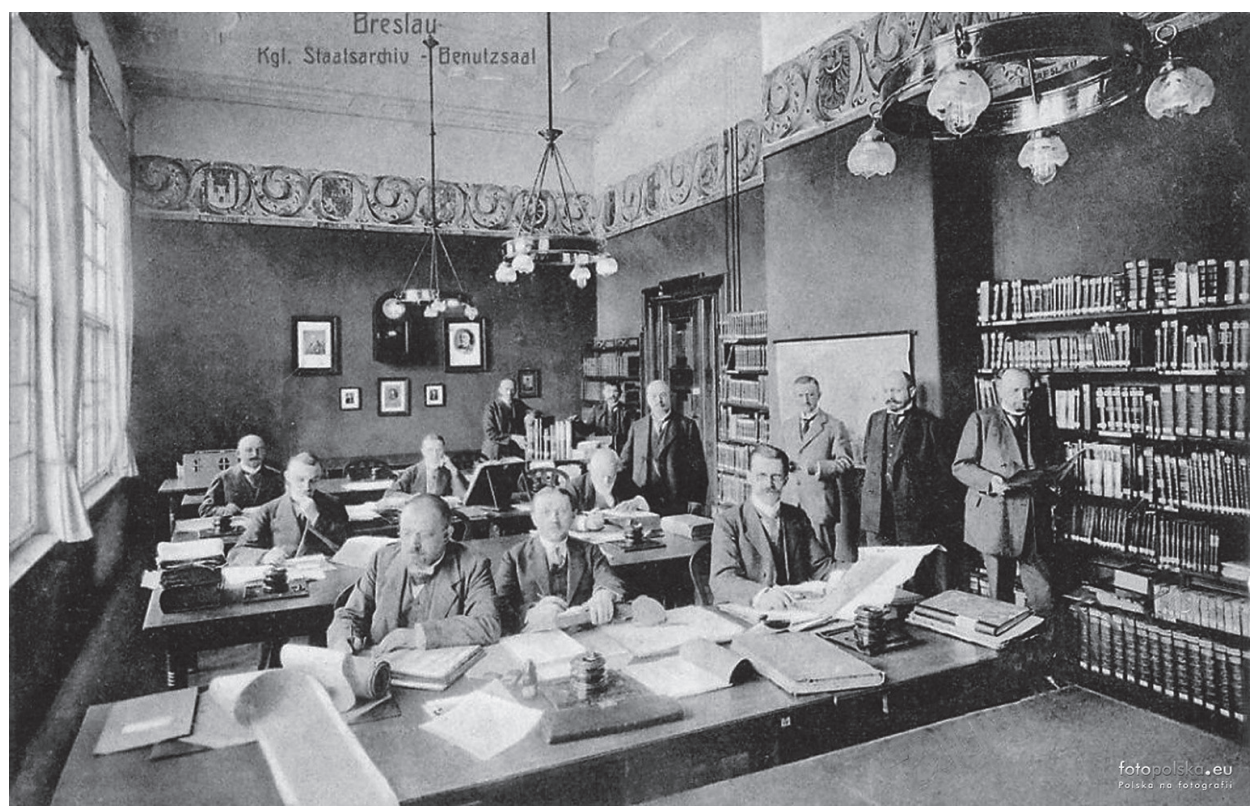

I1. 3. Pracownia Naukowa Archiwum Państwowego przy Tiergartenstrasse 13, ok. 1910 r. (http://www.fotopolska.eu/Wroclaw/b9004,Archiwum_Panstwowe.html?f=625689-foto; dostęp: 31.10.2017)

którymi dysponowały aktualnie lokale Biblioteki i Pracowni Naukowej. Zagwarantowanie $\mathrm{w}$ przemyślany sposób dodatkowych metrów z przeznaczeniem na magazyny biblioteczne zapewniał nowatorski projekt wybudowania specjalnego półpiętra z wykorzystaniem $2,28 \mathrm{~m}$, odebranych z wysokości znajdujących się pod nim pomieszczeń parteru. $\mathrm{Z}$ zasadniczego pokoju Biblioteki prowadziły doń na dół wąskie żelazne schody. W owym niskim pomieszczeniu magazynowym ulokowano książki w sześciu rzędach przy ścianach na kładkach regałów Lipmana oraz na stojącym pośrodku podwójnym regale identycznej konstrukcji. Jedyny mankament stanowiło nie dość wystarczające oświetlenie magazynu. Pomimo umieszczonych na suficie i na ścianach lamp elektrycznych niskie okno pokoju zaciemniał wystający ponad nim wykusz, ograniczając dostęp światła dziennego. Wychodząc naprzeciw rosnącym potrzebom i ambicjom w zakresie gromadzenia literatury archiwalnej, na półpiętrze zorganizowano nadto jeszcze jedno pojemne pomieszczenie, przewidziane do wykorzystania w celach bibliotecznych. Zlokalizowane w północnej części budowli łącznikowej stanowiącej odnogę budynku administracyjnego, również dostępne jedynie z głównego pokoju Biblioteki, służyć miało jako zapas powierzchni magazynowej dla przyszłych nabytków ${ }^{45}$.

45 Ibidem, s. 10-11. 
Zgromadzony do początku lat 40. XX wieku w liczbie ok. 30 tysięcy tomów księgozbiór Biblioteki Staatsarchiv Breslau ${ }^{46}$ stanowił ważną merytoryczną podporę w realizowaniu zasadniczych funkcji instytucji. Kolekcjonowany drogą zakupów, darów i wprowadzonej na szerszą skalę w II połowie XIX wieku wymiany dubletów, czego przykładem była owocna współpraca z wrocławską Biblioteką Miejską ${ }^{47}$, skompletował w szczególności wszystkie najbardziej znaczące historyczne silesiaca. W przypadku wymiany podstawą kalkulacji, tj. oszacowania wartości i równowartości publikacji, była liczba arkuszy dostarczonych dzie ${ }^{48}$. Wiadomo, że o kilkadziesiąt pozycji przydatnych w pracach nad opracowywaniem zasobu archiwalnego wzbogaciła się Biblioteka w roku 1910. W zamian za obejmujące 300 arkuszy 12-tomowe Novum Corpus Constitutionum (Berlin 1756-1822) zyskała książnica archiwalna wiele cennych pozycji tematycznych, wśród których znalazły się m.in.: Die innere Mission in Schlesien O. Schützego (Hamburg 1883), Über die Zustände der arbeitenden Klassen in Breslau A. Schneera (Berlin 1845), Die allgemeine Kirche J. Raebigera (Breslau 1845), Einige Worte über die in Schlesien den Rittergutsbesitzern zustehenden Rechte H. Hatzfeldta (Breslau 1848), Der Sozialismus und seine Gönner H. von Treitschkego (Berlin 1875) czy Die polnische Erhebung und die deutsche Gegenbewegung in Posen im Frühjahr 1848 R. Hepkego (Berlin 1848). W lutym 1912 roku księgozbiór archiwalny powiększył się zaś o otrzymane drogą wymiany roczniki „Schlesische Zeitung” z lat 1862-187249. Rozrastający się

46 Na podstawie: „Jahrbuch der Deutschen Bibliotheken” 33, 1942, s. 28.

47 Do pierwszej wymiany publikacji pomiędzy Archiwum Państwowym a Biblioteką Miejską doszło w 1878 roku. Z księgozbioru archiwalnego oddano wówczas m.in. sprawozdania z obrad byłego niemieckiego Bundestagu — Verhandlungen ehemaligen Deutschen Bundestages (Archiwum Państwowe we Wrocławiu, Akta miasta Wrocławia (dalej: APWr., Akta m. Wrocł.), sygn. III/31 920, s. 41 - sprawozdanie zbiorcze dyrektora H. Markgrafa z działalności Biblioteki Miejskiej w okresie od 1 kwietnia 1877 roku do 31 marca 1879 roku, z dnia 3 listopada 1879 roku). Wzajemne kontakty obu instytucji potwierdzać może fakt, iż od początku działalności Książnicy Miejskiej wśród jej donatorów wymieniano m.in. dyrektora Archiwum Państwowego C. Grünhagena, W. Wattenbach zasiadał zaś przez pewien czas w Kuratorium Rehdigerany, późniejszej Biblioteki Miejskiej. W tym samym 1878 roku gromadzony w bibliotece archiwalnej zbiór gazet, przy okazji oddania partii książek, przekazany został w liczbie kilkuset tomów Bibliotece Uniwersyteckiej we Wrocławiu (Minerva-Handbücher, Cz. 2. Die Archive, t. 1, pod red. P. Wentzckego, G. Lüdtkego, Berlin-Leipzig 1932, s. 48). Wiadomo również, że w 1912 roku wzajemna wymiana wzbogaciła Bibliotekę Miejską o 84 tomy druków nieprzydatnych w zasobie Biblioteki Archiwum Państwowego. O podobną liczbę tomów, których tytuły nie są niestety znane, powiększył się z kolei księgozbiór archiwalny (APWr., Akta m. Wrock., sygn. III/31 942, s. 196 — „Bericht über die Verwaltung der Stadtbibliothek und des Stadtarchivs zu Breslau im Rechnungsjahre 1912”).

48 APWr., Akta m. Wrocł., sygn. III/32 281, s. 33-35 (pismo dyrektora Archiwum Państwowego O. Meinardusa do dyrekcji Biblioteki Miejskiej we Wrocławiu w sprawie wymiany dubletów, z dnia 21 stycznia 1910 roku).

49 APWr., Akta m. Wrocł., sygn. III/32 283, s. 1 (pismo dyrektora Biblioteki Miejskiej M. Hippego do Archiwum Państwowego w sprawie przekazania bibliotece archiwalnej roczników „Schle- 
sukcesywnie zasób biblioteczny wzbogacały regularnie - dostarczane na zasadzie honorowego zobowiązania - egzemplarze tytułów opracowywanych na bazie materiałów archiwalnych. Posiadająca charakter wewnętrzny ${ }^{50}$ prezencyjna Biblioteka Archiwum Państwowego w opracowanych rękopiśmiennych katalogach książkowych i kartkowych informowała zarówno o drukach zwartych, jak i przechowywanych w niej niemieckich, polskich i czeskich czasopismach specjalistycznych $^{51}$. Co ważne, przed rokiem 1939 zaliczano jej zasób, wespół z kilkoma innymi księgozbiorami fachowymi, do najistotniejszych specjalistycznych zbiorów naukowych Wrocławia ${ }^{52}$. Biblioteką administrował, w ramach obowiązków służbowych, jeden z urzędników naukowych Archiwum. Wiadomo, że w roku 1942 była nim kobieta ${ }^{53}$.

Zasobność wrocławskiej książnicy archiwalnej, pod względem liczby zgromadzonych zbiorów, plasowała ją w latach 30 . XX wieku na szóstej pozycji w gronie bez mała 40 bibliotek funkcjonujących przy niemieckich archiwach państwowych ${ }^{54}$. Budżet roczny na zakup niezbędnej literatury opiewał na kwotę 500 marek, co — w zestawieniu z sumami będącymi w dyspozycji innych archiwów - nie stanowiło wygórowanej stawki. Dla przykładu, Biblioteka Archiwum

sische Zeitung”, z dnia 9 stycznia 1912 roku) oraz APWr., Akta m. Wrock., sygn. III/32 281, s. 36 (odpowiedź O. Meinardusa do dyrekcji Biblioteki Miejskiej, z dnia 15 stycznia 1912 roku, z adnotacją M. Hippego, z dnia 9 lutego 1912 roku).

50 Wypożyczanie na zewnątrz książek z biblioteki archiwalnej było zasadniczo wykluczone (na podstawie: Minerva-Handbücher..., loc. cit.).

51 Ibidem.

52 Mowa tu o, wyszczególnianych we wrocławskich rocznikach statystycznych wespół z Biblioteką Archiwum Państwowego, uznanych fachowych księgozbiorach istniejących przy poważniejszych instytucjach miasta, by wymienić chociażby największe: Bibliotekę Izby Przemysłowo-Handlowej (Industrie- und Handelskammer), Bibliotekę 8. Okręgu Wojskowego (Wehrkreisbücherei VIII), Bibliotekę Śląskiego Muzeum Rzemiosła Artystycznego i Starożytności (Schlesisches Museum für Kunstgewerbe und Altertümer), Bibliotekę Śląskiego Muzeum Sztuk Pięknych (Schlesisches Museum der bildenden Künste), Bibliotekę Instytutu Europy Wschodniej (Osteuropainstitut), Centralną Bibliotekę Ewangelicką Śląskiej Prowincji Kościelnej (Evangelische Zentralbibliothek für die Kirchenprovinz Schlesien) czy istniejącą do 1933 roku Bibliotekę Żydowskiego Seminarium Teologicznego Fundacji Fraenckla (Bibliothek des jüdisch-theologischen Seminars, Fraenckelsche Stiftung). Zasoby wymienionych książnic zazwyczaj nie przekraczały kilkunastu bądź kilkudziesięciu tysięcy tomów.

53 „Jahrbuch der Deutschen...”, loc. cit.

54 Większymi księgozbiorami dysponowały jedynie: Archiwum Państwowe w Hamburgu (Staatsarchiv der Freien und Hansestadt Hamburg) - 60 tysięcy t., Pruskie Tajne Archiwum Państwowe w Berlinie-Dahlem (Preussisches Geheimes Staatsarchiv) - 50 tysięcy t., Bawarskie Główne Archiwum Państwowe w Monachium (Bayerisches Hauptstaatsarchiv München) 32 tysiące t., Heskie Archiwum Państwowe w Darmstadt (Hessisches Staatsarchiv) - 30 tysięcy t. oraz Saksońskie Główne Archiwum Państwowe w Dreźnie (Sächsisches Hauptstaatsarchiv) 30 tysięcy t. (na podstawie: Minerva-Handbücher..., s. 30, 71, 81, 143, 237). 
Państwowego w Koblencji posiadająca liczebnie mniejszy księgozbiór wielkości 12 tysięcy tomów oraz Biblioteka Archiwum Państwowego w Wiesbaden, której zasób ograniczał się w tym czasie do 8 tysięcy tomów, miały do dyspozycji kwotę 400 marek rocznie, a zasobna w 10 tysięcy tomów Biblioteka Archiwum Państwowego w Schwerinie na rozbudowę księgozbioru przeznaczyć mogła aż 1100 marek $^{55}$. Pomimo ograniczonych finansów dynamiczny i regularny przyrost zasobu książnicy wrocławskiej gwarantować mogły w pełni efektywne inne sposoby pomnażania zbiorów.

Mozolnie kompletowane, nie bez trudu, od pierwszych dekad działalności instytucji bogate zbiory biblioteczne Staatsarchiv Breslau przepadły wraz ze zniszczeniem, w czasie oblężenia miasta w 1945 roku, siedziby archiwalnej przy Tiergartenstrasse ${ }^{56}$. Dzieło ponownego kształtowania od podstaw księgozbioru specjalistycznego polskiego Archiwum Państwowego we Wrocławiu podjęto już w pierwszych latach powojennych ${ }^{57}$. Ze swym porównywalnym obecnym bogactwem ilościowo-merytorycznym zasób ten — jakkolwiek w innej rzeczywistości i warunkach - jest dziś godnym kontynuatorem chwalebnych tradycji przedwojennych. Organizowany na drodze żmudnego procesu odtwarzania właściwej sobie struktury treściowej, obfity w wartościowe XVI-XX-wieczne silesiaca i wratislaviana, jako swoisty konglomerat rozmaitych proweniencji zdobył walor szczególny, stanowiąc obecnie doskonałe pole badawcze także na obszarze identyfikacji — niefunkcjonujących już samoistnie — dawnych, niejednokrotnie zapomnianych kolekcji książkowych ${ }^{58}$.

55 Ibidem, s. 48, 186, 317, 369.

56 Gmach Archiwum Państwowego znajdował się na trasie budowy pasa startowego lotniska, powstającego na rozkaz szefa wrocławskiej NSDAP Karla Hankego pomiędzy ówczesnym Kaiserbrücke (obecnie most Grunwaldzki), a Fürstenbrücke (obecnie most Szczytnicki). Ewakuację zbiorów archiwalnych przeprowadzano zaś już od połowy 1942 roku. Nie wiadomo jednakże, czy i w jakim stopniu objęła ona zbiory biblioteczne. Egzemplarze tytułów publikacji wymienionych w niniejszym artykule $\mathrm{z}$ racji ich gromadzenia w przedwojennym księgozbiorze archiwalnym, a przechowywanych w zbiorach obecnej Biblioteki Uniwersyteckiej, nie wykazują proweniencji dawnego Staatsarchiv Breslau.

57 Bibliotekę powojennego Archiwum Państwowego we Wrocławiu, w charakterze księgozbioru pomocniczego przy realizacji zadań archiwalnych, utworzono już w roku 1947. O organizacji i księgozbiorze Biblioteki zob. B. Kumor-Gomułka, Biblioteka Archiwum Państwowego we Wrocławiu, [w:] Archiwum Państwowe we Wrocławiu 1811-2011: przeszłość i współczesność, pod red. J. Drozda i J. Gołaszewskiego, Wrocław 2011, s. 191-202.

58 Zob. eadem, Jedno archiwum - niejeden ślad: tropem proweniencji ksiegozbioru historycznego Biblioteki Archiwum Państwowego we Wrocławiu (artykuł niepublikowany). 
BOŻENA KUMOR-GOMUŁKA

FROM A DISPUTE TO A BOOK COLLECTION, I.E. ON THE POST-SECULARISATION

ORIGINS AND DEVELOPMENT OF THE IDEA OF COLLECTING THE SPECIALIST

LITERATURE IN THE FORMER STATE ARCHIVES IN WROCŁAW (STAATSARCHIV BRESLAU) UNTIL 1945

\section{Summary}

Specialist literature collected from the first few decades of the existence of the State Archives in Wrocław was a form of specialist aid, with time becoming a collection complementing archive materials. The idea to compile the first independent collection emerged from a conflict between the first archivist, Johann Gustav Gottlieb Büsching and the director, from 1812, of the Central Silesian Library, located in the same building on the Sand Island, Johann Gottlob Schneider, an advocate of abolishing the existing privilege of free access of archivists to the library. The process of amassing archive literature was developed on a broader scale after Schneider's death in 1822. Among the first publications acquired by the director of the then Royal Silesian Provincial Archives (later State Archives), Gustav Adolf Harald Stenzel, were Johann Sinapius' Schlesische Curiositäten and Friedrich Vater's Repertorium der preussischen schlesischen Verfassung. Another source for obtaining specialist literature was regular donations from the Ministry of Internal Affairs. Considerable support for the creation of a typical archive library came from the director, from 1852, of the Prussian State Archives, Karl Wilhelm von Lancizolle, author of the first guidelines on collecting archive specialist literature. Soon another director of the Wrocław institution, Wilhelm Wattenbach, compiled a separate catalogue of acquisitions for the library collection. Eventually, the book collection of the former Staatsarchiv Breslau grew to about 30,000 volumes and contained all the most significant Silesian-themed works from the past. This made the Wrocław archive library ranked sixth among the forty libraries functioning in German state archives. However, the collection was lost when the Archives building in Tiergartenstrasse 13 was destroyed in 1945. Efforts to organise again specialist, Polish State Archives in Wrocław from scratch were undertaken already in the first few years after the second world war and have continued to this day.

KEY WORDS: State Archives in Wrocław, Staatsarchiv Breslau, specialist library 